\title{
Migraine Headache Triggered Specifically by Sunlight: Report of 16 Cases
}

\author{
Aslan Tekatas $^{\text {a }}$ Bulent Mungen $^{\mathrm{b}}$

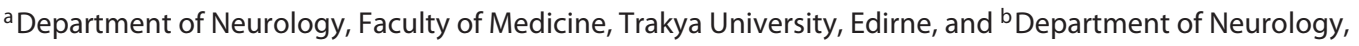 \\ Faculty of Medicine, Firat University, Elazig, Turkey
}

\section{Key Words}

Migraine $\cdot$ Headache $\cdot$ Sunlight $\cdot$ Trigger $\cdot$ Retrospective

\begin{abstract}
Migraine headaches may take place due to various triggering factors. One or more triggering factors can be detected in a migraine patient. To our knowledge, a factor that is known to trigger migraine attacks in a patient does not cause headache each time the patient is exposed to it. Migraine headaches also can be experienced without these factors. Here, we describe a case series of 16 sunlight-induced migraine patients. Records of patients admitted to Firat University Faculty of Medicine Clinic of Neurology with a complaint of headache between January 2001 and June 2010 were scanned. Among those patients, the ones suffering headaches after being exposed to sunlight were examined comprehensively. Nine patients were female and 7 were male. Fourteen patients had the characteristics of migraine without aura, while 2 patients had the characteristics of migraine with aura. The mean times to headache onset after sunlight exposure were 5-10 $\mathrm{min}$ in summer and 60 min in winter. Migraine headaches can be triggered by many different causes. We view sunlight as a single triggering factor which should be questioned in migraine patients.
\end{abstract}

(c) 2013 S. Karger AG, Basel

\section{Introduction}

Migraine headaches with or without aura may occur due to various triggering factors. One or more triggering factors can be found to be responsible for the headaches in a migraine patient $[1,2]$. Several studies have shown that stress, hormonal instability, sleep disorders, consumption of some kinds of food and beverages, weather changes, and exposure to sunlight can induce migraine headaches to varying degrees [3-10]. To our knowledge, a factor that is known to trigger migraine attacks in a patient does not always cause headaches whenever a patient is exposed to it. Both exogenous and endogenous triggering factors, including genetic factors [11] and central $[12,13]$ and peripheral sensitization $[14,15]$, are thought to precipitate attacks. In a recent study, it was reported that in some migraine cases, particularly with aura, certain triggering factors initiate the attacks frequently or always [5]. However, migraine headaches may occur at other times, without responsible catalyzing factors in these cases.

In this study, patients who have migraine headache with or without aura provoked specifically by sunlight and patients who have never suffered headaches unless being exposed to sunlight were presented.

\section{KARGER}

E-Mail karger@karger.com www.karger.com/ene
(C) 2013 S. Karger AG, Basel

0014-3022/13/0706-0263\$38.00/0
Aslan Tekatas, MD

Trakya Universitesi

Tip Fakültesi

Nöroloji Anabilim Dali, TR-22030 Edirne (Turkey)

E-Mail atekatas@hotmail.com 


\section{Materials and Methods}

We reviewed the data of 2,957 patients with headache admitted to Firat University, Faculty of Medicine, Department of Neurology, Headache Clinic between January 2001 and June 2011. Twenty patients with the symptom of headache after being exposed to sunlight were chosen and invited to the neurology clinic by accessing their address information in their files. A further detailed medical history was taken by interviewing the patients for headache characteristics. Four patients in whom we failed to make a differential diagnosis between migraine and other headaches were excluded from the study. In the remaining 16 patients, migraine diagnosis was confirmed based on the criteria of the International Headache Society [16]. For all of the patients, physical and neurologic examinations, routine blood and urine tests, and cranial computed tomography or magnetic resonance imaging scans were in the normal limits. None of them had a history of cigarette or alcohol use or drug addiction. Before starting the study, informed written consent was obtained from each patient and the study was approved by the local ethics committee.

\section{Results}

Patient characteristics are listed in table 1 . There were 9 women and 7 men, and the mean age was 34.4 years (range: 16-63). The mean age for onset of headaches was 26.1 years (range: 14-47). The mean duration of disease was 8.3 years (range: 2-30). Fourteen patients showed characteristics of migraine without aura, whereas the other two showed characteristics of migraine with aura. All of the patients stated that their headaches start out mildly and get worse over time. The onset of headache following sunlight exposure varied with season. It took 5-10 min in summer and $60 \mathrm{~min}$ in winter.

\section{Discussion}

The main and novel finding of this study is that there may be a special subgroup of patients with migraine in whom the only and unique triggering factor is sunlight exposure. In patients with migraine headache, bright light is a common cause among the triggering factors. Curiously, a known triggering factor in a migraine patient provokes only some of the migraine attacks. In other words, those triggering factors do not initiate each migraine attack of the patients [1]. Yet, in a recent study, it was reported that in some migraine cases, several triggering factors initiate the attacks frequently or always [5]. However, migraine headaches may occur at other times without triggering factors. Our cases had headaches specifically after being exposed to sunlight always in summer and frequently in winter. The most important difference that separates our cases from others is the headaches have never appeared unless being exposed to sunlight.

The mechanism of provoking or worsening migraine headaches with light is unclear. Noseda et al. [17] proposed modulation of sensitive thalamocortical neurons in the dura mater via nonimage-forming retinal pathways as a possible mechanism. In our cases, this triggering effect on the brain through the retina and optic nerve might be different from other migraine patients. Chakravarty [18] claimed that variation in the intensity of the stimuli, such as brightness of sunlight, is a triggering factor in migraine headaches. Accordingly, our patients experienced more intense and frequent attacks during summer when the sunlight is more effective and bright. In addition, there is compelling evidence to suggest that 5-hydroxy-tryptamine, calcitonin gene-related peptide, and nitric oxide might play important roles in some aspects of migraine pathogenesis. Ultraviolet radiation in the sunlight alters calcitonin gene-related peptide and nitric oxide release by intraepidermal sensory nerve fibers in the skin [19]. This condition might have a role in triggering the attacks via vasodilatation.

Besides the brightness of sunlight, temperature may be considered as another triggering factor. As expected, during summer the sun is brighter and the temperature is higher than in winter. Higher temperatures may stimulate cutaneous thermoreceptors, which in turn may lead to migraine attacks. In fact, our patients stated that in summer their headaches lasted longer and were more intense than in winter. The underlying reason for this can be the higher temperature in summer caused by the sun. Our patients, however, never suffered headaches when they were exposed to heat caused by other sources (e.g. having a bath with hot water, working in hot places like a bakery, entering a hot room on a cold day). Thus, we think that the heat from the sun does not affect the migraine headaches, but the bright light of the sun and the intensity of the light could have an effect on those patients. Some of our patients prevented their headaches by avoiding sunny places (e.g. going for a picnic or vacation at the seaside, walking outside, and swimming), especially in summer. This condition, in part, limits the patients' social life. Some of other patients preferred to wear a hat when they were in sunny places. These patients reported that it was possible to prevent the attack by wearing a hat. Wearing a hat or a helmet may be useful for some patients in preventing migraine attacks. Some patients pointed out that they feel more comfortable and delay the head- 
Table 1. Demographics and some clinical characteristics of the headache

\begin{tabular}{|c|c|c|c|c|c|c|c|c|}
\hline $\begin{array}{l}\mathrm{Pa}- \\
\text { tient }\end{array}$ & $\begin{array}{l}\text { Age/ } \\
\text { gender }\end{array}$ & $\begin{array}{l}\text { Duration, } \\
\text { years }\end{array}$ & $\begin{array}{l}\text { Onset period } \\
\text { in the sunlight, } \\
\text { min }\end{array}$ & Localization & $\begin{array}{l}\text { Severity } \\
\text { of headache }\end{array}$ & Coexisting signs & Season & Headache relief method \\
\hline 1 & $36 / \mathrm{m}$ & 6 & $30-60$ & $\begin{array}{l}\text { forehead and top } \\
\text { of the head }\end{array}$ & severe & $\begin{array}{l}\text { pressure feeling in the } \\
\text { head and fatigue }\end{array}$ & summer & sleeping in the dark \\
\hline 2 & $36 / \mathrm{m}$ & 11 & $15-20$ & $\begin{array}{l}\text { forehead and top } \\
\text { of the head }\end{array}$ & $\begin{array}{l}\text { moderate } \\
\text { or severe }\end{array}$ & $\begin{array}{l}\text { feeling heaviness on } \\
\text { the head }\end{array}$ & every season & resting in the dark \\
\hline 3 & $30 / f$ & 10 & $5-10$ & $\begin{array}{l}\text { forehead and bilateral } \\
\text { retroorbital region }\end{array}$ & severe & $\begin{array}{l}\text { feeling heaviness on } \\
\text { the head }\end{array}$ & every season & sleeping in the dark \\
\hline 4 & $51 / f$ & 10 & $15-20$ & one side of the head & $\begin{array}{l}\text { moderate } \\
\text { or severe }\end{array}$ & $\begin{array}{l}\text { heaviness on eyelids } \\
\text { and seeing bright lights }\end{array}$ & every season & sleeping in the dark \\
\hline 5 & $29 / f$ & 3 & $20-25$ & top of the head & $\begin{array}{l}\text { moderate } \\
\text { or severe }\end{array}$ & $\begin{array}{l}\text { pressure feeling in the } \\
\text { head and fatigue }\end{array}$ & summer & resting in the dark \\
\hline 6 & $63 / f$ & 16 & $15-20$ & bilateral temporal & moderate or severe & burning feeling in the eyes & summer & resting in the dark \\
\hline 7 & $55 / f$ & 30 & $15-20$ & $\begin{array}{l}\text { top of the head and } \\
\text { bilateral temporal region }\end{array}$ & $\begin{array}{l}\text { moderate or } \\
\text { severe }\end{array}$ & $\begin{array}{l}\text { burning feeling in the eyes } \\
\text { and heaviness on eyelids }\end{array}$ & summer & sleeping in the dark \\
\hline 8 & $24 / f$ & 3 & $20-30$ & top of the head & moderate & red eyes & summer & $\begin{array}{l}\text { taking analgesics or } \\
\text { sleeping in the dark }\end{array}$ \\
\hline 9 & $16 / \mathrm{m}$ & 2 & $25-30$ & forehead & moderate or severe & - & every season & sleeping in the dark \\
\hline 10 & $34 / \mathrm{m}$ & 20 & 20 & $\begin{array}{l}\text { forehead and bilateral } \\
\text { temporal region }\end{array}$ & moderate & - & every season & $\begin{array}{l}\text { taking analgesics and } \\
\text { resting in the dark }\end{array}$ \\
\hline 11 & $27 / f$ & 8 & 30 & $\begin{array}{l}\text { forehead and bilateral } \\
\text { temporal region }\end{array}$ & moderate & $\begin{array}{l}\text { heaviness on eyelids, } \\
\text { lacrimation and redness } \\
\text { on eyes }\end{array}$ & summer & $\begin{array}{l}\text { taking analgesics or } \\
\text { sleeping in the dark }\end{array}$ \\
\hline 12 & $21 / f$ & 3 & $15-20$ & occipital region & $\begin{array}{l}\text { moderate } \\
\text { or severe }\end{array}$ & $\begin{array}{l}\text { lacrimation and redness } \\
\text { on eyes }\end{array}$ & summer & resting in the dark \\
\hline 13 & $48 / \mathrm{m}$ & 2 & 60 & whole head & $\begin{array}{l}\text { moderate } \\
\text { or severe }\end{array}$ & - & summer & $\begin{array}{l}\text { taking analgesics or } \\
\text { sleeping in the dark }\end{array}$ \\
\hline 14 & $21 / \mathrm{f}$ & 2 & $15-20$ & $\begin{array}{l}\text { forehead, top of the } \\
\text { head and bilateral } \\
\text { temporal region }\end{array}$ & $\begin{array}{l}\text { moderate } \\
\text { or severe }\end{array}$ & redness on eyes & summer & $\begin{array}{l}\text { taking analgesics and } \\
\text { resting in the dark }\end{array}$ \\
\hline 15 & $40 / \mathrm{m}$ & 4 & $30-60$ & top of the head & severe & $\begin{array}{l}\text { heaviness on eyelids and } \\
\text { seeing bright lights }\end{array}$ & summer & $\begin{array}{l}\text { washing head with } \\
\text { cold water and } \\
\text { resting in the dark }\end{array}$ \\
\hline 16 & $20 / \mathrm{m}$ & 3 & $30-40$ & $\begin{array}{l}\text { forehead and top } \\
\text { of the head }\end{array}$ & moderate & redness on eyes & summer & $\begin{array}{l}\text { taking analgesics and } \\
\text { resting in the dark }\end{array}$ \\
\hline
\end{tabular}

ache by wearing sunglasses on sunny days. However, they stated that the risk of having a headache increases as the duration of exposure to sunlight lengthens. Therefore, sunglasses were not the best solution. Avoiding sunlight and having a little sleep seemed to be the most effective prevention for some of the headaches in our patients. In many cases, taking an analgesic drug without sleeping was not enough to ease the pain.

In conclusion, the main aspect that distinguishes our cases from other migraine patients is that the headaches never occurred due to any triggering factor except bright sunlight. In this particular patient group, the only triggering factor was the sunlight exposure. This may have some implications in the management of migraine patients and prevention of attacks. Thus, we suggest that patients with headache should be questioned in this regard as well as the other conditions. There may be a special subgroup of patients with migraine in whom the only triggering factor is sunlight exposure. We think that more comprehensive future clinical trials will shed light on questions about whether these kinds of cases are a type of migraine or not. 


\section{References}

1 Zagami AS, Bahra A: Symptomatology of migraines without aura; in Olesen J, Goadsby PJ, Ramadan NM, Tfelt-Hansen P, Welch KM (eds): The Headaches, ed 3. Philadelphia, Lippincott Williams \& Wilkins, 2006, pp 399405.

2 Olesen J, Goadsby PJ: Synthesis of migraine mechanisms; in Olesen J, Goadsby PJ, Ramadan NM, Tfelt-HansenP, Welch KM (eds): The Headaches, ed 3. Philadelphia, Lippincott Williams \& Wilkins, 2006, pp 393-398.

3 Kelman L: The triggers or precipitants of the acute migraine attack. Cephalalgia 2007;27: 394-402.

4 Hauge AW, Kirchmann M, Olesen J: Characterization of consistent triggers of migraine with aura. Cephalalgia 2011;31:416-438.

5 Hauge AW, Kirchmann M, Olesen J: Trigger factors in migraine with aura. Cephalalgia 2010;30:346-353.

-6 Wöber C, Holzhammer J, Zeitlhofer J, Wessely P, Wöber-Bingöl C: Trigger factors of migraine and tension-type headache: experience and knowledge of the patients. J Headache Pain 2006;7:188-195.
7 Ravishankar K: 'Hair wash' or 'head bath' triggering migraine - observations in $94 \mathrm{In}$ dian patients. Cephalalgia 2006;26:13301334.

8 Holzhammer J, Wöber C: Alimentary trigger factors that provoke migraine and tensiontype headache (in German). Schmerz 2006; 20:151-159.

9 Bekkelund SI, Hindberg K, Bashari H, Godtliebsen F, Alstadhaug KB: Sun-induced migraine attacks in an Arctic population. Cephalalgia 2011;31:992-998.

10 Russell MB, Rasmussen BK, Fenger K, Olesen J: Migraine without aura and migraine with aura are distinct clinical entities: a study of four hundred and eighty-four male and female migraineurs from the general population. Cephalalgia 1996;16:239-245.

11 Russell MB, Iselius L, Olesen J: Migraine without aura and migraine with aura are inherited disorders. Cephalalgia 1996;16:305-309.

12 Goadsby PJ, Bartsch T: On the functional neuroanatomy of neck pain. Cephalalgia 2008;28(suppl 1):1-7.

13 McMahon SB, Lewin GR, Wall PD: Central hyperexcitability triggered by noxious inputs. Curr Opin Neurobiol 1993;3:602-610.
14 Strassman AM, Raymond SA, Burstein R: Sensitization of meningeal sensory neurons and the origin of headaches. Nature 1996;384: 560-564.

15 Dubner R: Basic mechanisms of pain associated with deep tissues. Can J Physiol Pharmacol 1991;69:607-609.

16 Headache Classification Subcommittee of the International Headache Society: The International Classification of Headache Disorders: 2nd edition. Cephalalgia 2004;24(suppl 1):9160 .

17 Noseda R, Kainz V, Jakubowski M, Gooley JJ, Saper CB, Digre K, Burstein RA: Neural mechanism for exacerbation of headache by light. Nat Neurosci 2010;13:239-245.

-18 Chakravarty A: How triggers trigger acute migraine attacks: a hypothesis. Med Hypotheses 2010;74:750-753.

19 Misery L: The neuro-immuno-cutaneous system and ultraviolet radiation. Photodermatol Photoimmunol Photomed 2000;16:78-81. 